essay was prompted by a consideration of work in Renaissance studies by no means implies the Renaissance is a privileged site for such work; if anything, homohistory argues against the privileging of distinct chronological difference.

The most useful point in Dinshaw and Lochrie's letter, then, is not the incompatible desire to assert the medieval in the face of attempting to destroy chronology as the basis for what we do. Rather, it is their question of how we may practically study desire without being bound by "traditional disciplinary boundaries and periodizations." One answer, which is so important that it formed the title for the essay, is by queering history-and by queering the parameters within which we are medievalists, early modernists, or modernists. This "new" configuration of the discipline might return to a past in which these distinctions did not exist in the form they do today. Or it might spurn that past and focus only on the today. Either way, our relation to history is complex and anachronistic, as Dipesh Chakrabarty has shown so compellingly in his work on decolonization. The temporal version of decolonization - what may be termed dechronolizationwould involve taking anachronism seriously and defying difference as the underwriter of history.

At that perhaps never-to-be-achieved date, we will finally be rid of beige.

Madhavi Menon American University

\section{Pragmatism and Principle}

\section{To THE Editor:}

A few days ago, I read Robert Scholes's Forum reply to James D. Hoff, on the issue of pragmatism and principle (PMLA 121 [2006]: 297-98). What Scholes said there seems to me to be mistaken. I would like to convey my reasons for disagreement.

Scholes offers the lone example of slavery and suggests that we really need to say that it is wrong. This would be a matter of principle and, as such, would "not be subject to change." Principle is based on "fixed belief."

In taking this position, he has overlooked the changing historical view of slavery. Before 1700, few people thought slavery was wrong in principle. A lot of people thought it was perfectly all right.
As many students of history have pointed out, Aristotle thought slavery was normal; he did not criticize it. Jesus did not object to it. The "fixed belief" to which Scholes appeals simply did not exist.

Even today, where slavery exists in various parts of the globe, I venture to say that some of the slaveholders and their suppliers (now often referred to as those who traffic in humans) believe that there is nothing wrong with what they are doing. They see no universal, unchanging principle such as Scholes is using in his argument against Hoff. They also might maintain that what they are engaging in is not slavery at all, as it has been traditionally defined. For some forms of human trafficking as it exists today, the definition of slavery might have to be adjusted to make it applicable to new developments.

This does not mean that pragmatists in the United States today-or in the Western world, or in most of the world-would seriously argue on behalf of slavery or that they would contend that this issue should be debated all over again. Pragmatists, like anyone else, can learn from historical experience. We don't have to find out now if slavery is wrong: it has been found to be wrong. It is dehumanizing. John Dewey was right: when we have "warranted assertability" to declare something is wrong, then we have reached a determination of an issue. Yes, at that point, there are "reasonable grounds for connecting our beliefs to the world," as Scholes desires. But we are human beings who know our fallibility. For the Peircean view of pragmatism, the acknowledgment of fallibility is essential. Followers of Richard Rorty cannot be faulted for asserting that if we had not been products of the Western world, it is utterly unlikely that our view of slavery would ever have evolved to its present principled form. People like Scholes may believe that they are relying on a principle that has been and will be unchanging, that they are speaking from a "fixed" position, but that is an illusion. It may have become a fixed position for most of us now, but it took a lot of critique and reappraisal for it to reach such a status.

I grant that Scholes's principled stand-and the similar stand of millions of other people-will help prevent the human race from slipping back into widespread acceptance of slavery. But that amounts to saying that principles have pragmatic value. They "work." 
Pragmatism comes in when there are live issues that need to be dealt with. Whenever that occurs, Hoff's formulation of “a set of principles and beliefs that are constantly subject to critique and change" is sane and healthy (120 [2006]: 296). This does not imply that such principles may be thrown out at will. To suggest, as Scholes does, that Hoff's position involves only passion and is bereft of reason is false. Hoff rightly says that in practicing pragmatism, "we must recognize the effects, large and small, that our beliefs make manifest in the world." That takes reasoning. "Pragmatism is inherently a critical endeavor."

Hoff's letter is a brief statement of a philosophical position and cannot be taken as a fullscale defense of pragmatism. On the other hand, Scholes's remarks can be taken as a full-scale rejection of pragmatism. If Richard Rorty, Stanley Fish, and other neopragmatists are the real problem, as Scholes says, then he should not have written in such a way as to imply that pragmatism as a general philosophical position is the target of his criticism.

Arthur Efron University at Buffalo

\section{Reply:}

Arthur Efron's letter is both smart and thoughtful, so much so that it may be unanswerable. I may simply have been wrong to insist that there are moral principles immune to historical change. Certainly, I agree that the example of slavery is vulnerable to the critique Efron has proposed. But this is a complex issue. If we can examine history and see Britain and America evolve from acceptance of slavery to rejection of it, we can then ask what drove this evolution in belief. I would like to suggest that the principle was there all along but that it took us some time to discover it. Some people, as Efron points out, still do not acknowledge it. From the perspective I am proposing, this might mean that they are behind us in historical development. Such a view, I am aware, appears dangerously Hegelian, but it seems to me no more dangerous than allowing modern slave drivers the right to the opinions of their own interpretive communities.

Efron offers me a way out, of course. I can be critical of neopragmatists, he suggests, without blaming pragmatism. And I do take issue with neopragmatists and have done so for some time. But pragmatism itself, it seems to me, claims to be based on a fixed principle, or perhaps a metaprinciple that assumes that fixed principles do not exist in our world. To this we might add, as Stanley Fish would no doubt suggest, that such principles should not exist and that this is a good thing, too. And that further step might be used to distinguish the new from the old pragmatism.

What worries me most about the view I am opposing is that it seems to leave no room for reason or persuasion in human affairs. If we cannot appeal to principles, how can we reason with others? And how can we teach our young people about ethical matters? It is not enough, I think, to say simply that this is the way we do things, or this is the way we think now and it is right because it is we who think it and now when we think it. If it goes against the principles of pragmatism to believe in fixed principles, the paradoxical nature of this situation may help us to maintain our view that some values are better than others, because they are closer to the principles that lie at the end of the evolutionary road. And I think we need to believe that they are there, no matter how skeptical we must be about our ability to attain them.

Robert Scholes Brown University 